Jurnal Keuangan dan Perbankan, Vol.19, No.3 September 2015, hlm. 368-377

Terakreditasi SK. No. 040/P/2014

http://jurkubank.wordpress.com

\title{
EX-DIVIDEND DATE DAN PERUBAHAN HARGA SAHAM
}

\author{
Novriyanthi Taungke \\ Supramono \\ Fakultas Ekonomika dan Bisnis Universitas Kristen Satya Wacana
}

\begin{abstract}
A bstract
The aim of this study is to anal yze whether the stock prices decrease at ex-dividend date in Indonesia Stock Exchange (ID X) that is determined by amount of dividend drop-off ratio (DDR). This study al so attempts to investigatethe differ ences the stock prices decrease at ex-dividend date based on Investment 0 pportunity Set (IOS). Sample consist of the companies that announced the dividend during 2010-2012 periods. By using non-parametric tests, especially $\mathrm{Chi}$-square Test and $\mathrm{M}$ ann W hitney Test, theresult of this study show ed the stock prices decreased less than dividend amount on ex-dividend date. Besides, thenon-growth firms experienced decreasemorethan growth firms.
\end{abstract}

Keyw ords- ex-dividend date, dividend drop-off ratio, IOS

Di tengah rencana PT Astra International Tbk (ASII) membagikan dividen, pergerakan saham ASII pagi ini (11/9) terbilang fluktuatif. Data RTI menunjukkan, pada pukul 10.03, saham ASII kembali ke level pembukaan yaitu Rp 6.350. Padahal, pada transaksi sebelumnya, saham produsen otomotif ini sempat naik ke posisi Rp 6.400 dan turun ke level Rp 6.250.... (Kontan, 11 September 2013).

Kutipan berita di atas menunjukkan rencana pembagian dividen oleh PT Astra International Tbk menyebabkan harga saham fluktuatif. Dengan demikian dapat dikatakan bahwa ada indikasi pengumuman dividen memiliki kandungan informasi. Hal ini sejalan dengan teori signaling yang menyatakan pengumuman dividen dapat digunakan untuk mengirim sinyal tentang prospek perusahaan kepada investor. Beberapa peneliti telah membuktikan bahwa pengumuman dividen memberikan sinyal berupa abnormal return di sekitar pengumuman dividen (Supramono, 2000; Capstaff et al. 2004; Yilmaz dan Sel cuk, 2010; Taneem dan Yucee, 2011).

Berkenaan dengan pengumuman dividen ada beberapa tanggal penting antara waktu pengumuman dividen sampai pembayaran dividen, salah satunya adalah ex-dividend date, secara teoretis pada tanggal tersebut harga saham seharusnya mengalami penurunan sebesar dividen yang dibayarkan karena investor investor yang membeli saham pada saat

Koresponden dengan Penulis

Supramono: Telp/Fax +62 298311881

E-mail : supramono@staff.uksw.edu 


\section{Ex-Dividend Date dan Perubahan Harga Saham}

N ovriyanthi Taungke \& Supramono

ex-dividend date atau setelah ex-dividend date, maka yang memiliki hak atas dividen adalah pemilik saham sebelumnya. M eskipun begitu, perubahan harga saham di sekitar ex-dividend datemenjadi perdebatan para peneliti. Milonas et al. (2002) menyatakan bahwa perdebatan perubahan harga saham pada ex-dividend date berawal dari penelitian Elton dan Gruber pada tahun 1970 yang menemukan bahwa harga saham jatuh dengan jumlah yang lebih kecil dari dividen karena berhubungan dengan pajak dividen, sebaliknya Kalay (1982) me nemukan bahwa penurunan harga di sekitar exdividend datetidak berhubungan dengan efek pajak. Penelitian selanjutnya yang dilakukan oleh M ilonas dan Travlos (2001), Milonaset al . (2002), dan Yahyaee et al (2008) juga membuktikan harga saham mengalami penurunan kurang dari besaran dividen pada ex-dividend date.

Sementara itu penelitian perubahan harga seputar ex-dividend date di Indonesia antara Iain telah dilakukan oleh Sularso (2003), Siaputra dan Atmadja (2006), dan Firmansyah dan Violita (2007). Namun, penelitian tersebut masih fokus pada abnormal return, tidak meneliti mengenai seberapa besar penurunan harga saham pada exdividend date jika diukur dengan dividend drop-off ratio (DDR). Selain itu, tidak mengaitkan dengan pertumbuhan perusahaan. Padahal, bagi perusahaan yang memiliki nilai atau pertumbuhan yang bagus dimata investor ada kemungkinan tidak terjadi penurunan harga saham pada ex-dividend date. Investor lebih mengedepankan capital gain dimasa datang. Berdasarkan celah penelitian tersebut dalam penelitian ini diajukan dua pertanyaan penelitian yaitu pertama, apakah terdapat penurunan harga saham pada ex-dividend date di Bursa Efek Indonesia yang di ukur dengan dividend dropoff ratio (DDR). Kedua, apakah terdapat perbedaan perubahan harga saham pada ex-dividend date antara perusahaan bertumbuh dan tidak bertumbuh.

\section{PENGEMBANGAN HIPOTESIS}

Penelitian terdahulu seperti Elton \& Gruber (1970) dan Kalay (1982) telah menguji penurunan harga saham pada ex-dividend date dibandingkan dengan dividen per saham. Elton \& Gruber membuktikan secara empirik bahwa pada ex-dividend date nilai dividend drop-off ratio menghasilkan nilai yang lebih kecil dari dividen per lembar saham. Selain itu, Elton \& Gruber menjelaskan bahwa fenomena ex-dividend date didasarkan pada perbedaan tarif pajak terhadap pendapatan dividen dan capital gain untuk marginal long-term investor.

Penelitian Frank dan Jagannathan (1988) menunjukan bahwa walaupun tanpa kehadiran pajak, harga saham jatuh pada saat ex-dividend date yaitu setengah dari jumlah dividen yang dibayarkan. Pada bursa saham Cina Milonas et al. (2002) menemukan dividen yang tidak kena pajak menunjukkan harga saham jatuh pada hari ex-dividend dengan jumlah yang sama dengan dividen sedangkan untuk dividen kena pajak, penyesuaian harga tergantung pada tarif pajak yang berlaku atas penghasilan dividen. Hal yang sama juga di temukan oleh Yahyaee et al. (2008) yang meneliti di Oman, dimana tidak diberlakukan pajak terhadap dividen dan capital gain. Yahyaee et al. membuktikan meskipun tanpa kehadiran pajak atas dividen dan capital gain, harga saham jatuh saat ex-dividend date tetapi dengan jumlah yang kurang dari nilai dividen. Borges (2008) meneliti di bursa saham Portugal juga menemukan harga saham turun pada saat ex-dividend date tidak disebabkan oleh tax clientele.

Dari hasil penelitian yang diuraikan di atas mengindikasikan bahwa tanggal ex-dividend menyebabkan penurunan harga saham maka dapat dirumuskan hipotesis sebagai berikut,

$\mathrm{H}$ 1: Harga saham turun pada ex-dividend date di Bursa Efek Indonesia. 


\section{Jurnal Keuangan dan Perbankan | KEUANGAN}

Vol. 19, N o.3, September 2015: 368-377

Sebenarnya penurunan harga saham tersebut tidak terlepas adanya prospek pertumbuhan perusahaan dimasa datang. Hartono (2009) menjelaskan pertumbuhan perusahaan sering diukur dengan investment opportunity set (IOS). Penelitian yang dilakukan oleh Pratiska (2013) menemukan bahwa terdapat hubungan positif antara IOS dan nilai perusahaan. Ini berarti nilai perusahaan ditentukan oleh adanya IOS. Smith \& Watts (1992) dan Gaver \& Gaver (1993) menggunakan rasio nilai pasar dibagi dengan nilai buku sebagai proksi dari IOS dalam mengukur perusahaan yang mengal ami pertumbuhan. Perusahaan yang bertumbuh mempunyai rasio lebih besar dari satu. $\mathrm{Hal}$ ini berarti bahwa pasar percaya nilai pasar perusahaan tersebut lebih besar dari nilai bukunya. Terdapat lima proksi IOS yang umum digunakan seperti pada penelitian Eriyana (2002) dan Setyaningsih (2005) yaitu PPE/ BVA (rasio book value of gross property, plant and equipment to the book value of assets), MVE/ BVE (rasio market to book value of equity), MVA/ BVA (rasio market to book value of assets), PER (price to earning), dan CAP/ BVA (ratio capital addition to assets book value).

A da kemungkinan investor kurang memperhatikan hilangnya peluang memperoleh dividen tetapi lebih mempertimbangkan peluang pertumbuhan investasi dari perusahaan. Perusahaan yang mempunyai pertumbuhan bagus kemungkinan harga saham tidak turun pada saat ex-dividend date, bahkan mengalami kenaikan. Sebaliknya, perusahaan yang tidak memiliki pertumbuhan yang bagus mungkin akan mengalami penurunan harga saham pada ex-dividend date. Dengan demikian perubahan harga saham pada ex-dividend date tergantung dari pertumbuhan perusahaan maka dapat disusun suatu hipotesis sebagai berikut;

H2: Terdapat perbedaan perubahan harga saham antara perusahaan bertumbuh dan tidak bertumbuh pada ex-dividend date.

\section{METODE}

Populasi dalam penelitian ini adalah perusahaan yang terdaftar di Bursa Efek Indonesia (BEI). Data merupakan data sekunder yang diperoleh dari pojok bursa UNDIP dan www.idx.co.id.. Teknik pengambilan sampel dengan menggunakan purposive sampling dengan beberapa kriteria sebagai berikut: (1) Perusahaan yang terdaftar di BEI antara tahun 2010-2012 (2) Perusahaan membagikan cash dividend selama periode penelitian (3) Kelengkapan data mengenai closing price di sekitar ex-dividend date selama periode penelitian (4) Tersedianya laporan keuangan perusahaan selama periode penelitian untuk penggunaan proksi IOS (5) Perusahaan tidak melakukan corporate action lain pada event window.

Setelah data yang diperoleh memenuhi kriteria yang diuraikan di atas, hipotesis pertama akan diuji secara keseluruhan selama periode2010-2012. Sedangkan untuk menguji hipotesis kedua berdasarkan pertumbuhan perusahaan, sampel yang telah memenuhi ke lima kriteria di atas akan dipilih berdasarkan pertumbuhan perusahaan. Untuk itu dalam mengelompokkan perusahaan bertumbuh dan tidak bertumbuh digunakan proksi IOS (Investment O pportunity Set). Berdasarkan lima kriteria di atas maka diperoleh 212 perusahaan yang akan diobservasi selama periode 2010-2012. Sedangkan berdasarkan kriteria IOS diperoleh 191 perusahaan bertumbuh dan 191 perusahaan tidak bertumbuh selama periode 2010-2012.

Dengan asumsi tidak adanya biaya transaksi, ekuilibrium penurunan harga (price drop) dapat dirumuskan sebagai berikut,

$\frac{\left(\boldsymbol{P}_{c u m}-\boldsymbol{P}_{e x}\right)}{D}=\frac{1-\boldsymbol{t}_{d}}{1-\boldsymbol{t}_{c g}}$

dimana,

$P_{\text {cum }}=$ harga saham pada cum-dividend date,

$P_{e x}=$ harga saham yang diharapkan pada ex dividend date, 


\section{Ex-Dividend Date dan Perubahan Harga Saham}

N ovriyanthi Taungke \& Supramono

D = nilai dividen,

$t_{d}=$ pajak dividen,

$\mathrm{t}_{\mathrm{cg}} \quad=$ pajak capital gain. menjadi

Persamaan di atas dapat dituliskan kembali

$D D R=\frac{\left(\boldsymbol{P}_{\text {cum }}-\boldsymbol{P}_{e x}\right)}{\boldsymbol{D}}$

Dimana

DDR adalah Dividend Drop-Off Ratio (DDR) yang merupakan besarnya penurunan harga saham pada saat ex-dividen date dibandingkan dengan nilai dividen yang dibayarkan

Pertumbuhan perusahaan (growth) menunjukkan adanya investment opportunity set (IOS) atau dengan kata lain saham perusahaan memberikan peluang investasi di masa mendatang (Hartono, 2009). Pengukuran faktor IOSyang digunakan pada penelitian ini melibatkan 5 rasio keuangan seperti yang diuraikan pada tabel 1 .

Jumlah faktor yang digunakan adalah faktorfaktor yang memiliki nilai eigennya sama dengan satu atau melebihi total communalities dari semua variabel yang digunakan. Kemudian dijumlahkan dan diperingkat dari yang tertinggi ke nilai terendah. Empat puluh persen indeks tertinggi merupakan klasifikasi perusahaan bertumbuh dan empat puluh persen indeks terendah merupakan klasifikasi perusahaan tidak tumbuh sedangkan indeks faktor yang berada di tengah dua puluh persen dihilangkan karena dianggap kurang esktrim untuk membedakan klasifikasi perusahaan.

\section{HASIL}

Data tahun 2010 menunjukkan bahwa ada sebanyak 144 perusahaan yang melakukan pengumuman cash dividend, tahun 2011 sebanyak 163 perusahaan dan tahun 2012 terdapat 169 perusahaan. Untuk menghitung besar penurunan dividen digunakan rumus rata-rata dividend dropoff ratio (DDR) menggunakan persamaan: $P_{\text {aum }}-P_{e x} / D$. Statistik deskriptif mengenai cash dividend, harga saham pada cum-dividend date, harga saham pada ex-dividend date, dan dividend drop-off ratio (DDR) yang disajikan pada tabel 2 .

Tabel 1. Proksi IOS

\begin{tabular}{|c|c|c|}
\hline Variabel & Perhitungan & Keterangan \\
\hline PPE/ BVA & $\frac{\text { nilai buku aktiva tetap }}{\text { nilai buku total aktiva }}$ & $\begin{array}{l}\text { Rasio book value of } \\
\text { gross property, plant } \\
\text { and equipment to the } \\
\text { book value of assets. }\end{array}$ \\
\hline MVE/ BVE & $\frac{\text { (Jumlah saham beredar } \times \text { Harga penutupan saham) }}{\text { Total ekuitas }}$ & $\begin{array}{l}\text { Rasio market to book } \\
\text { value of equity. }\end{array}$ \\
\hline PER & $\frac{\text { Harga penutupansaham }}{E P S}$ & $\begin{array}{l}\text { Rasio price to } \\
\text { earning. }\end{array}$ \\
\hline MVA/ BVA & $\frac{(\text { Total aktiva }- \text { Total ekuitas })+(\text { Saham beredar } \times \text { Harga penutupan })}{\text { Total aktiva }}$ & $\begin{array}{l}\text { Rasio market to book } \\
\text { value of assets. }\end{array}$ \\
\hline CAP/ BVA & $\frac{\text { Tambahan modal dalam satu tahun }}{\text { Total aktiva }}$ & $\begin{array}{l}\text { Rasio capital addition } \\
\text { to assets book value. }\end{array}$ \\
\hline
\end{tabular}




\section{Jurnal Keuangan dan Perbankan | KEUANGAN}

Vol. 19, N o.3, September 2015: 368-377

Tabel 2. Statistik Deskriptif

\begin{tabular}{lrrrr}
\hline & Dividen & $\begin{array}{r}\text { Harga saham } \\
\text { Cum-dividend }\end{array}$ & $\begin{array}{r}\text { H arga saham } \\
\text { Ex-dividend }\end{array}$ & D D R \\
\hline Mean $(\bar{x})$ & 316.97 & 9341.90 & 9280.70 & 0.36 \\
Stand deviation & 1765.90 & 48173.49 & 48118.88 & 3.01 \\
Minimum & 0.45 & 50.00 & 50.00 & -13.80 \\
Maximum & 24074.00 & 708000.00 & 708000.00 & 42.00 \\
$\mathrm{~N}$ & 540 & 540 & 540 & 540 \\
\hline
\end{tabular}

Statistik deskriptif menunjukkan bahwa ratarata cash dividend yang dibagikan sebesar Rp 316,97 per lembar saham. Standar deviasi cash dividend memiliki nilai yang lebih besar dari nilai rata-rata cash dividend yang menunjukkan terdapat kesenjangan yang cukup besar antara nilai minimum dan maksimum cash dividend. Rata-rata harga saham pada cum-dividend date sebesar Rp 9.341,90 dan pada ex-dividend date mengalami penurunan sehingga rata-rata harga saham menjadi Rp 9.280,90. Selanjutnya, statistik deskriptif juga menunjukkan rata-rata DDR sebesar 0,36 selama periode 20102012. Hasil tersebut mengindikasikan bahwa selama periode 2010-2012 harga saham pada saat exdividend datemengalami penurunan $36 \%$ dari nilai dividen yang dibayarkan.

Untuk menentukan jenis teknik analisis yang akan digunakan dalam pengujian hipotesis maka terlebih dahulu harus diketahui distribusi data melalui uji normalitas. Dalam hal ini menggunakan uji Kolmogorov Sminorv. Jika nilai sig. $<0,05$ berarti data berdistribusi tidak normal, sebaliknya jika nilai sig. > 0,05 maka data berdistribusi normal. H asil uji normalitas cash dividend, harga saham pada cum-dividend date, harga saham pada ex-dividend date, dan dividend drop-off ratio (DDR) menunjukkan nilai sig. $<0,05$. Hasil tersebut membuktikan bahwa data untuk variabel yang digunakan selama periodepenelitian tidak berdistribusi normal. Data tersebut juga tidak berdistribusi normal ketika dilakukan transformasi data. Oleh karena itu, pengujian yang dilakukan pada penelitian ini menggunakan metode non-parametrik.
Untuk kepentingan pwngujian hipotesis pertama bahwa terdapat penurunan harga saham dividen pada saat ex- deviden date tersebut maka dilakukan uji perbedaan proporsi antara sampel yang mengalami penurunan harga saham, kenaikan harga saham dan tidak mengalami perubahan harga saham (tetap) pada saat ex-deviden date pada periode 2010-2012 dengan menggunakan uji Chi-square. Sampel yang menghasilkan DDR $>0$ dikelompokkan ke dalam kelompok sampel yang mengalami penurunan harga saham. Sedangkan sampel yang memiliki DDR <0 dikelompokkan ke dalam kelompok sampel yang mengalami kenaikan harga saham dan untuk sampel yang memiliki $\mathrm{DDR}=0$ dikelompokkan ke dalam kelompok tetap. Berikut hasil uji Chi-square perubahan harga saham pada ex-dividend date yang disajikan pada tabel 3.

Tabel 3. Hasil Uji Chi-Square (Goodness of Fit) Proporsi Harga Saham Turun, Naik dan Tetap Saat Ex-dividend date

\begin{tabular}{lrrrc}
\hline & Observed N & $\begin{array}{c}\text { Chi- } \\
\text { Square }\end{array}$ & Df & $\begin{array}{c}\text { Asymp. } \\
\text { Sig }\end{array}$ \\
\hline Turun & 268 & 84.133 & 2 & $0.000^{*}$ \\
Naik & 94 & & & \\
Tetap & 178 & & & \\
Total & 540 & & & \\
\hline
\end{tabular}

* Keterangan: Tingkat Signifikansi 0,05

Dari hasil uji chi-square menunjukkan nilai probabilitas statistik atau Asymp sig. sebesar 0.000 lebih kecil dari tingkat signifikansi 0.05 sehingga secara statistik terdapat perbedaan antara proporsi sampel yang mengalami penurunan harga saham, kenaikan harga saham dan yang tidak mengalami 


\section{Ex-Dividend Date dan Perubahan Harga Saham}

N ovriyanthi Taungke \& Supramono

perubahan harga saham pada ex-dividend date. Hasil yang diperoleh membuktikan bahwa selama periodepenelitian banyak sampel yang mengalami penurunan harga saham pada ex-dividend date yaitu sebanyak 268 sampel, dibandingkan yang mengalami kenaikan harga saham yang hanya terjadi pada 94 sampel. Sedangkan 178 sampel tidak menunjukkan adanyakenaikan maupun penurunan harga saham pada ex-dividend date. Oleh karenaitu, hipotesis pertama diterima yaitu terjadi penurunan harga saham pada ex-dividen date di Bursa Efek Indonesia (BEI).

Untuk kepentingan pengujian hipotesis kedua pada penelitian ini yang menyatakan adanya perbedaan perubahan harga saham pada ex-dividend date antara perusahaan bertumbuh dan tidak bertumbuh maka sampel di bagi ke dalam kelompok perusahaan bertumbuh dan tidak bertumbuh dengan menggunakan anal isisfaktor. Langkah pertama dalam analisis faktor adalah menilai apakah variabel yang digunakan layak untuk dimasukkan dalam analisis selanjutnya. Untuk mengetahui layak atau tidaknya analisis faktor yang digunakan dapat dilihat melalui nilai KMO dan nilai M easure of Sampling A dequacy (MSA). Variabel layak dianalisis lebih lanjut jika memiliki nilai KMO dan MSA diatas 0,5. Setelah dilakukan uji analisisfaktor ternyata walaupun nilai KMO sudah memenuhi persyaratan tetapi nilai M easure of Sampling Adequacy (MSA) secara parsial belum memenuhi persyaratan kelayakan maka variabel-variabel belum dapat dianalisis lebih Ianjut. Oleh karena itu, langkah selanjutnya adalah mengeluarkan variabel yang memiliki nilai MSA yang paling kecil. Kemudian dilakukan kembali analisis faktor pada variabel-variabel yang telah lolos uji kelayakan. Sehingga anal isis faktor baik tahun 2010, 2011 dan 2012 layak untuk dianalisis lebih lanjut. Berikut tabel 4 menyajikan nilai KMO dari sampel yang digunakan.

Pada tabel 4 terlihat bahwa nilai KMO untuk tahun 2010, 2011 dan 2012telah menunjukkan kelayakan untuk dianal isis lebih lanjut. Jadi, indeks fak- tor yang digunakan untuk sampel 2010 dan 2012 setelah mengeluarkan variabel CAP/ BVA ada 4 variabel yaitu PPE/ BVA, MVA/ BVA, MVE/ BE dan PER. Sedangkan indeks faktor yang digunakan untuk sampel 2011 setelah mengeluarkan variabel PER ada 4 variabel yaitu PPE/ BVA, MVA/ BVA, MVE/ BE dan CAP/ BVA. Indeksfaktor yang digunakan setiap tahun dijadikan dasar dalam pengelompokkan perusahaan bertumbuh dan perusahaan tidak bertumbuh. Selanjutnya, indeks faktor IOSyang telah diperoleh dijumlahkan dan diurutkan dari yang terbesar sampai yang terkecil. Kemudian $40 \%$ faktor IOS tertinggi dikelompokkan sebagai perusahaan bertumbuh, $40 \%$ faktor IOS terendah dikel ompokkan sebagai perusahaan tidak bertumbuh, dan $20 \%$ ditengah-tengah dikeluarkan dari penelitian.

Tabel 4. KM O and Bartlett's Test

\begin{tabular}{ccrrr}
\hline & $\mathbf{2 0 1 0}$ & $\mathbf{2 0 1 1}$ & $\mathbf{2 0 1 2}$ \\
\hline $\begin{array}{c}\text { Kaiser-M eyer- } \\
\text { Olkin MSA. }\end{array}$ & Approx. & 274.346 & 138.453 & 263.499 \\
& $\begin{array}{l}\text { Chi- } \\
\text { Square }\end{array}$ & 6.525 & 0.512 \\
$\begin{array}{l}\text { Bartlett's Test } \\
\text { of Sphericity }\end{array}$ & Df & 6 & 6 & 6 \\
& Sig & 0.000 & 0.000 & 0.000 \\
\hline
\end{tabular}

Langkah selanjutnya adalah melakukan perhitungan dividend drop-off ratio (DDR) dan uji beda rata-rata DDR dengan uji $\mathrm{M}$ ann-W hitney antara perusahaan bertumbuh dan tidak bertumbuh. Hasil statistik deskriptif dari dividend drop-off ratio (DDR) dan uji beda rata-rata $M$ ann-W hitney disajikan pada tabel 5 .

Dari tabel statistik deskriptif menunjukkan rata-rata penurunan harga saham atau dividend drop-off ratio padakelompok perusahaan bertumbuh sebesar 0,150 dan 0,498 pada kel ompok perusahaan tidak bertumbuh. Hasil tersebut mengindikasikan harga saham pada ex-dividend date untuk perusahaan bertumbuh mengalami penurunan se- 


\section{Jurnal Keuangan dan Perbankan | KEUANGAN}

Vol. 19, N o.3, September 2015: 368-377

besar $15 \%$ dari nilai dividen. Sedangkan pada perusahaan yang tidak bertumbuh penurunannya lebih besar yaitu 49,8\% dari nilai dividen. Hasil ini juga membuktikan bahwa harga saham turun kurang dari besaran dividen yang seharusnya diterima oleh pemegang saham pada ex-dividend date. Namun, pada perusahaaan bertumbuh rata-rata penurunan harga saham lebih kecil dibandingkan rata-rata penurunan harga saham pada perusahaan tidak bertumbuh.

Tabel 5. Statistik Deskriptif dividend drop-off ratio (DDR) dan Uji Mann-Whitney Perusahaan Bertumbuh dan Perusahaan Tidak Bertumbuh

\begin{tabular}{lrr}
\hline \multicolumn{3}{c}{ Statistik D eskriptif } \\
\hline & $\begin{array}{c}\text { Perusahaan } \\
\text { Bertumbuh }\end{array}$ & $\begin{array}{c}\text { Perusahaan Tidak } \\
\text { bertumbuh }\end{array}$ \\
\hline Mean $(\bar{x})$ & 0.150 & 0.498 \\
Standar deviation & 2.709 & 3.712 \\
Minimum & -13.799 & -12.500 \\
Maximum & 17.241 & 42.000 \\
$\mathrm{~N}$ & 233 & 204 \\
\hline \multicolumn{3}{c}{ Uji M ann-Whitney } \\
\hline Mann-Whitney U & DDR \\
Wilcoxon W & 20152.000 \\
Z & -2.7913 .000 \\
Asymp. Sig. & $0.005 *$ \\
(2-tailed) & \\
* Keterangan: Tingkat Signifikansi 0,05
\end{tabular}

Hasil uji M ann-W hitney menunjukkan besar A symp. Sig < 0.05 yang berarti bahwa terdapat perbedaan rata-rata DDR yang signifikan antara perusahaan bertumbuh dan tidak bertumbuh. Hasil ini membuktikan bahwa hipotesis kedua diterima.

Untuk mengetahui apakah sektor tertentu mengalami penurunan harga lebih besar pada saat ex-dividen datedibandingkan sektor lainnya maka dilakukan tambahan analisis berdasarkan sektor. Dalam penelitian ini sampel dibagi kedalam sektor Finance dan $\mathrm{N}$ on-Finance. Hasil perhitungan DDR dan uji $\mathrm{M}$ ann-W hitney sektor Finance dan $\mathrm{N}$ on-Finance dapat di lihat pada tabel 6 .
Tabel 6. Statistik Deskriptif dividend drop-off ratio (DDR) dan Uji M ann-Whitney sektor Finance dan Non Finance

\begin{tabular}{lrr}
\hline \multicolumn{3}{c}{ Statistik D eskriptif } \\
\hline & Sektor Finance & $\begin{array}{c}\text { Sektor } \\
\text { N on-Finance }\end{array}$ \\
\hline Mean $(\bar{x})$ & 0.617 & 0.304 \\
Standar deviation & 2.480 & 3.109 \\
Minimum & -10.000 & -13.799 \\
Maximum & 17.241 & 42.000 \\
$\mathrm{~N}$ & 89 & 451 \\
\hline \multicolumn{3}{c}{ Uji Mann-Whitney } \\
\hline Mann-Whitney U & 17627.000 \\
Wilcoxon W & 119553.000 \\
Z & -1.849 \\
Asymp. Sig. & $0.064 * *$ \\
(2-tailed) & \\
* * Keterangan: Tingkat Signifikansi 0,1
\end{tabular}

Berdasarkan tabel 6 sektor Finance mengalami penurunan harga saham yang lebih besar yaitu $61,7 \%$ dari nilai dividen yang dibayarkan sedangkan sektor $\mathrm{N}$ on-Finance hanya turun sebesar 30,4 \% dari nilai dividen. Hasil perhitungan dari kedua kelompok sektor industri menunjukkan bahwa rata-rata harga saham mengalami penurunan pada saat ex-dividend datekurang dari nilai dividen yang dibayarkan. Selanjutnya, hasil perhitungan uji beda rata-rata $M$ ann-W hitney memberi bukti bahwa terdapat perbedaan DDR yang signifikan berdasarkan sektor industri yang ditunjukkan oleh nilai A symp. Sig. sebesar 0,064 kurang dari nilai signifikansi 0,1.

\section{PEMBAHASAN}

Hasil perhitungan yang telah diuraikan di atas membuktikan bahwa nilai dividend drop-off ratio (DDR) kurang dari besarnya dividen yang dibagikan yaitu sebesar 0.36 atau $36 \%$ dari jumlah dividen yang dibayarkan. Hasil ini juga didukung oleh pengujian yang menunjukkan terdapat perbedaan proporsi yang signifikan antara sampel yang mengalami penurunan harga saham dengan sampe 


\section{Ex-Dividend Date dan Perubahan Harga Saham}

N ovriyanthi Taungke \& Supramono

yang mengalami kenaikan harga saham dan yang tidak mengalami perubahan harga saham pada exdividend date selama periode 2010-2012. Proporsi sampel yang mengalami penurunan sebanyak 268 pengumuman dan proporsi sampel mengalami kenaikan harga saham sebanyak 94 pengumuman. Sedangkan proporsi sampel yang tidak mengalami perubahan harga saham pada ex-dividend date sebanyak 178. Terlihat jelas bahwa pada ex-dividend date harga saham sebagian besar mengalami penurunan.

Hasil tersebut dapat menunjukan bahwa dividen masih menjadi pertimbangan investor di Bursa Efek Indonesia untuk berinvestasi di instrumen saham. Hasil ini juga sejalan dengan hasil penelitian terdahulu yang membuktikan bahwa harga saham jatuh lebih kecil dari besarnya dividen pada ex-dividend date (Elton \& Gruber, 1970; Kalay 1982; Yahyaee et al., 2008; Borges, 2008). Turunya dividen tersebut sebenarnya juga dapat dijelaskan melalui Bird-in-the-hand theory yang menyatakan bahwa investor lebih menyukai dividen dibandingkan capital gain dengan anggapan bahwa dividen lebih pasti dibandingkan capital gain sehingga dividen sangat cocok untuk investor yang kebanyakan bersifat risk averse. Meskipun begitu karena penurunan harga sahamyang tidak sebesar dividen memberikan indikasi bahwa investor di Indonesia juga mempertimbangkan prospek perusahaan dengan harapan dapat memperoleh capital gain.

Jika di lihat dari pertumbuhan perusahaan (IOS) ada kemungkinan harga saham tidak mengalami penurunan yang tajam. Oleh karena itu, kemungkinan terdapat perbedaan perubahan harga saham antara perusahaan bertumbuh dan tidak bertumbuh. Nilai penurunan harga saham pada perusahaan tidak bertumbuh lebih besar hampir $50 \%$ dari jumlah dividen sedangkan penurunan harga saham yang terjadi pada perusahaan bertumbuh hanya sebesar 0,150 atau $15 \%$ dari jumlah dividen. $\mathrm{H}$ asil ini mengindikasikan bahwa investor juga memperhatikan pertumbuhan perusahaan dalam berinvestasi sehingga penurunan harga saham pada ex-dividend datelebih kecil terjadi pada perusahaan yang bertumbuh. Dengan demikian investor mau berkorban berupa "kerugian" jangka pendek akibat tidak memperoleh dividen, untuk mendapatan kompensasi yang jauh lebih besar berupa kenaikan harga saham dimasa datang atas saham yang dikoleksinya berasal dari perusahaan yang berprospek bagus.

Selain itu, hasil tambahan analisis juga membuktikan DDR yang dihasilkan oleh sektor Finance dan $\mathrm{N}$ on-finance menunjukkan adanya penurunan harga saham pada ex-dividend date. Namun, penurunan harga saham lebih besar terjadi pada sektor Finance yaitu $61,7 \%$ dari nilai dividen. Sedangkan sektor $\mathrm{N}$ on-finance hanya mengalami penurunan harga saham sebesar 30,4\%. Penurunan harga saham pada sektor Finance cukup besar menunjukan investor pada sektor financememiliki harapan besar bahwa dividen merupakan sumber utama pendapatan investasi dibandingkan capital gain yang memiliki ketidakpastian tinggi. Dengan kata lain, karena investor tidak memperoleh klaim dividen pada saat pembelian di ex-dividend date maka investor yang bersangkutan membutuhkan kompensasi berupa harga sahamyang relatif lebih murah.

\section{KESIM PULAN DAN SARAN}

\section{Kesimpulan}

Rata-rata harga saham pada ex-dividend date mengalami penurunan di Bursa Efek Indonesia (BEI) sebesar 36\% dari nilai dividen yang dibayarkan. Penurunan harga saham yang terjadi pada exdividend date ini memberikan indikasi bahwa investor memprioritaskan dividen atau lebih menyukai dividen. Perusahaan bertumbuh memiliki penurunan harga saham yang cenderung relatif lebih kecil dibandingkan perusahaan tidak bertumbuh. $\mathrm{Hal}$ ini mungkin terjadi karena investor lebih mengharapkan capital gain pada perusahaan yang bertumbuh. 


\section{Jurnal Keuangan dan Perbankan | KEUANGAN}

Vol. 19, N o.3, September 2015: 368-377

\section{Saran}

Hasil penelitian ini dapatmemberi implikasi bahwa bagi investor ada sebaiknya membeli saham pada ex-dividend date karena rata-rata harga saham pada tanggal ini menunjukkan penurunan harga sehingga investor dapat membeli saham dengan harga yang relatif murah. Sudah barang tentu dengan mempertimbangkan saham yang dibelinya merupakan saham perusahaan yang bertumbuh.

Penelitian ini tidak terlepas adanya keterbatasan sehingga terbuka peluang untuk perbaikan dimasa datang. Penelitian ini tidak memiliki data empirik mengenai preferensi investor apakah berdasarkan capital gain atau dividen. Untuk penelitian selanjutnya dapat menganalisis preferensi investor tersebut antara lain dengan melakukan eksperimen kepadamahasiswa. Dalameksperimen tersebut, mahasiswa diberikan studi kasus yang menunjukkan apakah investor lebih menyukai capital gain atau dividen dalam berinvestasi saham dan selanjutnya dikaitkan keputusan transaksi pada exdividend date.

\section{DAFTAR PUSTAKA}

Borges, M. R. 2008. The Ex-Dividend Day Stock Price Be havior: The Case of Portugal. International A tlantic Economic Society, 36(1), 15-30

Brigham, E. F. \& Houston, J. F. 2011. Buku 2: D asar-D asar $M$ anajemen Keuangan. Jakarta: Salemba Empat.

Capstaff, J. Klaeboe, A., \& Marshall, A.P. 2004. Share Price Reaction to Dividend Announcements: Empirical Evidence on the Signaling Model from the Oslo Stock Exchange. M ultinational Finance Journal.

Elton, E.J. \& M.J.Gruber.1970. Marginal Stockholder Tax Rate and Clientelle Effect. Review of Economic and Statistics, 52 (1) 68 - 74

Eriyana, S. 2002. Reaksi Pasar Terhadap Pengumuman Kenaikan Cash Dividend, Penurunan Cash Dividend, dan Stock Dividend Berdasarkan Pertumbuhan Investasi Perusahaan. Tesis. Magister Manajemen Universitas Kristen Satya Wacana.
Firmansyah, R. \& Violita, E.S. 2007. Analisis Pengaruh Pengumuman Ex-Dividend Date Terhadap Abnormal Return: Event Study pada Bursa Efek Jakarta. Jurnal A kuntansi dan Keuangan, 1(3), 249262

Frank, M. \& Jagannathan, R. 1998, “Why do stock prices drop by less than the value of the dividend? Evidence from a country without taxes", Journal of Financial Economics, 47 (2), 161"88.

Gaver, J.J. \& Kenneth M. Gaver, K.M. 1993. Addional Evidence on the association between the Investement opportunity Setand CoprortateFinancing, Dividen and Compensation Policies Journal of A ccounting and Economics, 126(1): 125 - 160

Hartono, J. 2009. Teori Portofolio dan A nalisis Investasi. Yogyakarta: BPFE.

Kalay, A.1982. The Ex-Dividen Day Behavior of Stock Price: A Re-Examination of the Clientelle Effect. Journal of Finance, 37, 1059-1070

Kontan. 2013. Berencana Bagi Dividen, Saham A SII Bergerak Liar. http:/ / investasi.kontan.co.id/ news/ berencana-bagi-dividen-saham-asii-bergerak-liar (Diakses tanggal 24 Juni 2014)

Miller, M. \& Modigliani, F. 1961. Dividend Policy, Growth and the Valuation of Shares. Journal of Business, 34, 411-433

Milonas, N.T. \& Travlos, N.G. 2001. TheEx-dividend Day Stock Price Behavior in the A thens Stock Exchange. Working Paper Series, Cardiff U niversity Business School, U K, June.

Milonas, N.T., Travlos, N., Xiao, J.Z. \& Tan, C. (2002). The Ex-Dividend Day Stock Price Behavior in the Chinese Stock Market. W orking Paper Series, Cardiff University Business School, UK, A pril.

Pratiska, S. 2013. Pengaruh IOS, Leverage, dan Dividend Yield Terhadap Profitabilitas dan Nilai PerusahaanSektor M anufaktur di BEI, h t t p : / / ojs.unud.ac.id/ index.php/ EEB/ article / view/ 4804/ 3750 (Di unduh 23 Juni 2014)

Samsul, M. 2006. Pasar M odal dan M anajemen Portfolio. Erlangga.

Sartono, R. A .2001. M anajemen Keuangan Teori dan A plikasi. Yogyakarta: BPFE-YOGYAKARTA. 


\section{Ex-Dividend Date dan Perubahan Harga Saham}

N ovriyanthi Taungke \& Supramono

Setyaningsih, 2005. Analisis Perbedaan Kebijakan Pendanaan, Dividend dan Return Saham pada Perusahaan yang Tumbuh dan Tidak Tumbuh dengan Pendekatan Proksi Investment O pportunity Set (IOS). Tesis. Magister Manajemen Universitas Kristen Satya Wacana.

Siaputra, L., dan Atmadja A.S. 2006. Pengaruh Pengumuman Dividen Terhadap Perubahan Harga Saham Sebelum dan Sesudah Ex-Dividend Date di Bursa Efek Jakarta (BEJ). Jurnal A kuntansi dan Keuangan, 8(1), 71-77.

Sularso, R.A. 2003. Pengaruh Pengumuman Dividen Terhadap Perubahan Harga Saham (Return) Sebelum dan Sesudah Ex- Dividend Date di Bursa Efek Jakarta (BEJ). Jurnal A kuntansi \& Keuangan, 5(1), $1-17$

Smith, C. W. Jr. \& Watts, R. L., 1992. The investment opportunity set and corporate financing, dividend and compensation policies. Journal of Financial Economics, 32, 263- 292
Supramono. 2000. Dividend Announcement Effect on Stock Return: A Test of Signaling Hypothesis in the Indonesian Stock Market. Gajah M ada International Journal of Business, 2,(September); 351 -368.

Taneem, S. \& Yuce, A . 2011. Information Content Of Dividend Announcements: An Investigation Of The Indian Stock Market. International Business \& Economics Research Journal - 10( 5),49-57.

Yahyaee, K.A., Pham, T. \& Walter, T. 2008. Ex-Dividend Day Behavior in the Absence of Taxes and Price Discreteness. International Review of Finance, 8 (34), 103-123.

Yilmaz, A.A \& Selcuk, E.(2010. Information Content of Dividends: Evidence from Istanbul. International Business Research 3(3),126-132 